\title{
PENGARUH KEBIJAKAN PEMERINTAH DAERAH DALAM KONSERVASI SUMBER DAYA AIR TERHADAP KESADARAN LINGKUNGAN MASYARAKAT KABUPATEN KUNINGAN
}

\author{
Suwari Akhmaddhian \\ Fakultas Hukum Universitas Kuningan \\ Email:suwariakhmaddhian@gmail.com
}

\begin{abstract}
Public awareness of the importance of a healthy and good environment continues to grow. The formulation of the problem is how the influence of government policy in conserving water resources on environmental awareness of the community in kuningan regency. The purpose of this research is to know how the influence of government policy in conserving water resources to environmental awareness of community in kuningan regency. This research can be practical and theoretical. The research method used by the researcher is using empirical juridical approach. Result of research The policy of local government in conserving water resources contained in Local Regulation of Regency of Kuningan Number 12 Year 2007 about Conservation of Water Resources to arrange society in the direction as desired by government of this blood start proved with existence of society awareness in environmental conservation that is with angry Community of kuningan district with logging tree in cilimus market. The conclusion of local government policy in conservation of water resources has been effective to increase public awareness in environmental conservation. Recommendations to increase awareness of the community hence the innovations needed to increase the awareness of the community through hygiene contests both at the sub-district or village level and explore the potential for increased environmental awareness through the excavation of local wisdom.

Keywords: Influence, Policy, Environmental Awareness.
\end{abstract}

\section{Abstrak}

Kesadaradaran masyarakat akan pentingnya lingkungan hidup yang sehat dan baik terus berkembang. Adapun rumusan masalah adalah bagaimana pengaruh kebijakan pemerintah dalam konservasi sumber daya air terhadap kesadaran lingkungan masyarakat di kabupaten kuningan. Adapun tujuan penelitian ini adalah untuk mengetahui bagaimana pengaruh kebijakan pemerintah dalam konservasi sumber daya air terhadap kesadaran lingkungan masyarakat di kabupaten kuningan. Penelitian ini dapat berguna secara praktis dan teoritis. Metode penelitian yang digunakan oleh peneliti adalah menggunakan pendekatan yuridis empiris. Hasil penelitian Kebijakan pemerintah daerah dalam konservasi sumber daya air tertuang dalam Peraturan Daerah Kabupaten Kuningan Nomor 12 Tahun 2007 tentang Konservasi Sumber Daya Air untuk mengatur masyarakat ke arah seperti yang diinginkan oleh pemerintah darah ini mulai terbukti dengan adanya kepedulian masyarakat dalam pelestarian lingkungan hidup yaitu dengan marahnya masyarakat kabupaten kuningan dengan penebangan pohon yang berada di pasar cilimus. Kesimpulan kebijakan pemerintah daerah dalam konservasi sumber daya air sudah efektif untuk meningkakan kesadaran masyarakat dalam pelestarian lingkungan hidup. Rekomendasi untuk meningkatkan kesadaram masyarakat maka diperlukan inovasi-inovasi untuk peningkatan kesadaran masyarakat tersebut melalui lomba-lomba kebersihan baik di tingkat kecamatan ataupun desa dan menggali potensi-potensi peningkatan kesadaran lingkungan melalui penggalian kearifan lokal.

Kata kunci : Pengaruh, Kebijakan, Kesadaran Lingkungan.

\section{PENDAHULUAN}

Lingkungan merupakan isu yang sedang berkembang di dunia bersamaan dengan Hak
Asasi Manusia dan Korupsi. Pelestarian alam di Indonesia secara hukum mengacu kepada beberapa Peraturan induk, yakni : Pertama, 
Undang-Undang Nomor 05 Tahun 1990 tentang Konservasi Sumberdaya Alam Hayati dan Ekosistemnya; Kedua, Undang-Undang Nomor 41 Tahun 1999 tentang Kehutanan; Ketiga, Undang-undang Nomor 32 tahun 2009 tentang Perlindungan dan Pengelolaan Lingkungan Hidup; Keempat, Undang-undang Nomor 21 Tahun 2014 tentang Konservasi Tanah dan Air. UndangUndang Nomor 05 Tahun 1990 tentang Konservasi Sumberdaya Alam Hayati dan Ekosistemnya bertitik berat pada pelestarian keanekaragaman hayati, baik keanekaragaman hayati hutan maupun bukan; baik di dalam kawasan hutan negara maupun di luarnya. Sedangkan Undang-Undang Nomor 41 Tahun 1999 tentang Kehutanan salah satunya mengatur konservasi alam di kawasan hutan negara; namun bukan hanya mencakup konservasi keanekaragaman hayati, melainkan meliputi pula perlindungan fungsi-fungsi penunjang kehidupan yang disediakan kawasan hutan. Undang-undang Nomor 32 tahun 2009 tentang Perlindungan dan Pengelolaan Lingkungan Hidup mengatur tentang perlindungan dan pengelolaan lingkungan hidup melalui instrumen hukum perdata, hukum administrasi dan hukum pidana. Undang-undang Nomor 21 Tahun 2014 tentang Konservasi Tanah dan Air mengatur tentang bagimana melakukan konservasi tanah dan air. Kabupaten Kuningan merupakan daerah pertanian berlokasi di kaki Gunung Ciremai dan memiliki sumber air melimpah, termasuk air tawar 620 mata air dan 43 sungai kecil dengan debit air total 8.352 liter / detik, dan karena itu penuh potensial agribisnis dan investasi dalam air berbasis perusahaan. Kabupaten Kuningan, adalah sebuah kabupaten di Provinsi Jawa Barat, Kabupaten ini terletak di bagian timur Jawa Barat, berbatasan dengan Kabupaten Cirebon di utara, Kabupaten Brebes (Jawa Tengah) di timur, Kabupaten Ciamis di selatan, serta di sebebelah barat Kabupaten Majalengka.

Permasalahan utama dalam lingkungan hidup yang teridentifikasi ada 5 (lima) antara lain ${ }^{1}$ : Pertama, kerusakan lahan akibat

1 Nana Sudiana dan Hasmana Soewandita, 2007, Pola penggundulan hutan, penebangan liar, alih fungsi lahan untuk perkebunan dan tanaman industri, penambangan minyak, industri dan permukiman; Kedua, abrasi pinggir sungai akibat laluintas pelayaran kapal-kapal besar dan cepat; Ketiga, pendangkalan sungai oleh tingginya erosi, abrasi dan sedimentasi; Keempat,. gangguan pola aliran air permukaan akibat alih fungsi lahan, keberadaan pelabuhan, dermaga, dan logpond; Kelima, penurunan kualitas air akibat buangan limbah cair industri, domestik pembuangan air ballast kapal, dan buangan limbah padat domestik. Pada tahun 2004 Pemerintah Kabupaten Kuningan melalui surat Nomor. 522/1480/Dishutbun tanggal 26 Juli 2004 perihal "Proposal Kawasan Hutan Gunung Ciremai sebagai Kawasan Pelestarian Alam" dan Pemerintah Kabupaten Majalengka melalui surat Nomor. 522/2394/Hutbun tanggal 13 Agustus 2004 perihal "Usulan Gunung Ciremai sebagai Kawasan Pelestarian Alam". Proposal usulan Bupati Kuningan ditindak lanjuti dengan Surat Bupati Kuningan kepada Ketua DPRD Kab. Kuningan melalui suratnya No. 522.6/1653/Dishutbun tanggal 13 Agustus 2004 perihal "Pengelolaan Kawasan Hutan Gunung Ciremai sebagai Kawasan Pelestarian Alam". Hal tersebut langsung mendapatkan respon dari DPRD Kab. Kuningan dengan mengirimkan surat kepada Menteri Kehutanan melalui surat pimpinan DPRD Kab. Kuningan Nomor. 661/266/DPRD perihal dukungan atas usulan pengelolaan kawasan hutan Gunung Ciremai menjadi kawasan taman nasional. Pengusulan tersebut dilatarbelakangi oleh fungsi ekologi Gunung Ciremai yang sangat besar khususnya sebagai daerah catchment area atau daerah tangkapan air yang sangat berperan penting sebagai penyediaan air baik sebagai bahan baku air minum maupun air irigasi pertanian bagi tiga kabupaten di sekitarnya yaitu Kuningan, Majalengka dan Cirebon. Sebelum menjadi kawasan taman nasional, saat zaman pemerintahan kolonial Belanda, kawasan

Konservasi Sumber Daya Air di Daerah Aliran Sungai Siak, Jurnal Alami Vol. 12 Nomor 1, Halaman. 44-51. 
hutan Gunung Ciremai sudah ditetapkan sebagai kawasan hutan tutupan atau hutan lindung.

Berdasarkan Surat Keputusan Menteri Kehutanan No. 424/Menhut-II/2004 tanggal 19 Oktober 2004 tentang perubahan fungsi kelompok hutan lindung pada kelompok hutan Gunung Ciremai seluas + 15.500 hektar yang terletak di Kabupaten Kuningan dan Majalengka, Propinsi Jawa Barat menjadi Taman Nasional Gunung Ciremai. Kabupaten Kuningan pada 2006 mendeklarasikan sebagai Kabupaten Konservasi dan selanjutnya terbit Peraturan-peraturan yang berkaitan dengan upaya Perlindungan dan Pengelolaan Lingkungan Hidup seperti Surat Keputusan Bupati Kuningan No.522/Kep.01HUTBUN/2006 tentang Penetapan Tanaman Endemik dan Langka Lokal Kabupaten Kuningan, Peraturan Daerah Kabupaten Kuningan Nomor 12 Tahun 2007 tentang Konservasi Sumber Daya Air, Peraturan Daerah Nomor 21 Tahun 2004 tentang Rencana Tata Ruang Wilayah Kabupaten Kuningan dan diperbaharui menjadi Peraturan Daerah Kabupaten Kuningan Nomor 26 Tahun 2011 Tentang Rencana Tata Ruang Wilayah Kabupaten Kuningan Tahun 2011 - 2031, Peraturan Daerah Kabupaten Kuningan Nomor 10 Tahun 2009 tentang Pelestarian Satwa Burung dan Ikan, Peraturan Daerah Kabupaten Kuningan Nomor 15 Tahun 2009 tentang Penngelolaan Air, Peraturan Daerah Kabupaten Kuningan Nomor 12 Tahun 2011 tentang Penyelenggaraan Kebun Raya Kuningan, Peraturan Daerah Kabupaten Kuningan Nomor 13 Tahun 2011 tentang Penatausahaan Hasil Hutan, Peraturan Daerah Kabupaten Kuningan Nomor 11 Tahun 2013 tentang Hutan Kota, Peraturan Daerah Kabupaten Kuningan Nomor 07 Tahun 2014 tentang Perlindunagn dan pengelolaan Lingkungan Hidup. ${ }^{2}$ oleh karena itu Kuningan sebagai kabupaten konservasi di perlukan peran dan partisipasi serta dukungan semua pihak yang terkait baik pemerintah daerah ataupun masyarakat kabupaten kuningan

2 Suwari Akhmaddhian, 2013, "Peran Pemerintah Daerah dalam Mewujudkan Hutan Konservasi Berdasarkan UndangUndang Nomor 41 Tahun 1999 Tentang Kehutanan (Studi di Kabupaten Kuningan)", Jurnal Dinamika Hukum . Vol. 13 No.3 September 2013, Purwokerto: FH Unsoed, hlm. 446-556. sehingga ketika dalam pemanfaatan sumber daya alam senantiasa memperhatikan keberlanjutan lingkungan hidup di kabupaten Kuningan. Maka dengan adanya penelitian ini diharapkan dapat mengukur dan mengetahui sejauh mana implementasi kebijakan pemerintah daerah dalam perlindungan dan pengelolaan lingkungan hidup sebagai upaya pelestarian lingkungan dan diharapkan hasil penelitian ini dijadikan landasan dan acuan dari pihak terkait dalam membuat atau memperbaiki kebijakan yang terkait perlindungan dan pengelolaan lingkungan hidup di kabupaten kuningan.

Masalah lingkungan hidup ini dapat ditinjau dari aspek medik, planologis teknologis, teknik lingkungan, ekonomi dan hukum. Hal ini dikemukakan oleh Siti Sundari Rangkuti yaitu Segi-segi hukum pengelolaan lingkungan hidup dan konservasi sumber daya alam di Indonesia perlu dikaji secara intensif, karena pengelolaan lingkungan tidak mungkin tanpa pengaturan hukum. Hal ini tidak berarti bahwa ahli hukum dapat menangani masalah lingkungan terlepas dari disiplin ilmu lain yang berkaitan dengan bidang lingkungan hidup ${ }^{3}$. Berdasarkan hal tersebut maka penulis tertarik untuk menulis penelitian dengan judul "Pengaruh kebijakan pemerintah daerah dalam konservasi sumber daya air terhadap kesadaran lingkungan masyarakat kabupaten kuningan)".

\section{RUMUSAN MASALAH}

Adapun yang menjadi pokok permasalahan yang akan menjadi fokus perhatian utama yang akan dibahas dalam penulisan ini yaitu Bagaimana Pengaruh kebijakan pemerintah daerah dalam konservasi sumber daya air terhadap kesadaran lingkungan masyarakat kabupaten kuningan?

\section{METODE}

Penelitian yang digunakan oleh penulis adalah yuridis empiris. Data yang digunakan

\footnotetext{
${ }^{3}$ Siti Kotijah, 2010, Implementasi Prinsip-prinsip Kehutanan dalam Rangka Konservasi Kehutanan: studi kasus di Jawa Timur, Jurnal Magister Hukum, Vol. 1 Nomor 2, Surabaya : Program Studi Magister Ilmu Hukum, Universitas Wisnuwardhana, Halaman. 354-386
} 
dalam penelitian ini adalah data primer yaitu wawancara dan data sekunder yaitu bahan hukum primer mulai dari UUD 1945, Undangundang Nomor 32 Tahun 2009 tentang Perlindungan dan Pengelolaan Lingkungan Hidup dan dan Peraturan Daerah Nomor 12 Tahun 2007 tentang Konservasi Sumber Daya Air, bahan hukum sekunder berupa jurnal, penelitian-penelitain terdahulu serta buu referensi yang relevan. Metode penelitian hukum, menurut Soerjono Soekanto adalah " suatu kegiatan ilmiah, yang di dasarkan pada metode, sistematika dan pemikiran tertentu, yang bertujuan mempelajari satu atau beberapa gejala hukum tertentu, dengan menganalisanya .

\section{PEMBAHASAN}

Pengaruh Kebijakan Pemerintah Daerah Dalam Konservasi Sumber Daya Air Terhadap Kesadaran Lingkungan Masyarakat Kabupaten Kuningan.

Konsep kebijakan atau dalam bahasa inggris sering kita dengar dengan istilah policy. Dalam Kamus Besar Bahasa Indonesia, kebijakan diartikan sebagai rangkaian konsep dan asas yang menjadi garis besar dan dasar rencana dalam pelaksanaan suatu pekerjaan, kepemimpinan, dan cara bertindak (tentang pemerintahan, organisasi, dsb); pernyataan citacita, tujuan, prinsip dan garis pedoman untuk manajemen dalam usaha mencapai sasaran. Carl $\mathrm{J}$ Federick sebagaimana dikutip Leo Agustino mendefinisikan kebijakan sebagai serangkaian tindakan/kegiatan yang diusulkan seseorang, kelompok atau pemerintah dalam suatu lingkungan tertentu dimana terdapat hambatanhambatan (kesulitan-kesulitan) dan kesempatan-kesempatan terhadap pelaksanaan usulan kebijaksanaan tersebut dalam rangka mencapai tujuan tertentu. Pendapat ini juga menunjukan bahwa ide kebijakan melibatkan perilaku yang memiliki maksud dan tujuan merupakan bagian yang penting dari definisi kebijakan, karena bagaimanapun kebijakan harus menunjukan apa yang sesungguhnya dikerjakan daripada apa yang diusulkan dalam beberapa kegiatan pada suatu masalah.
Amara Raksasataya mengemukakan Kebijaksanaan sebagai suatu taktik dan strategi yang diarahkan untuk mencapai tujuan. Suatu kebijaksanaan menuntut 3 (tiga) elemen yaitu : 1) Identifikasi dari tujuan yang ingin dicapai; 2) Taktik atau strategi dari berbagai langkah untuk mencapai tujuan yang diinginkan; 3) Penyediaan berbagai input untuk memungkinkan pelaksanaan secara nyata dari taktik strategi ${ }^{4}$. Menurut Carl L. Friedrich adalah serangkaian tindakan yang diusulkan seseorang, kelompok atau pemerintah dalam suatu lingkungan tertentu, dengan ancaman dan peluang yang ada, di mana kebijakan yang diusulkan tersebut ditujukan untuk memanfaatkan potensi sekaligus mengatasi hambatan yang ada dalam rangka mencapai tujuan tertentu. ${ }^{5}$

Adanya permasalah yang timbul di masyarakat merupakan agenda tetap bagi pemerintah untuk mencari solusi yang terbaik dalam pemecahannya berupa kebijakan. Ciri-ciri khusus yang melekat dalam pada kebijakan yaitu $^{6}$ : Pertama, Kebijakan lebih merupakan tindakan yang mengarah pada tujuan daripada sebagai perilaku atau tindakan yang serba acak dan kebetulan, dan merupakan tindakan yang direncanakan; Kedua, Kebijakan pada hakikatnya terdiri atas tindakan-tindakan yang salin terkait dan berpola mengarah pada tujuan tertentu yang dilakukan oleh pejabat-pejabat pemerintah dan bukan merupakan keputusankeputusan yang berdiri sendiri; Ketiga, Kebijakan bersangkut paut dengan apa yang senyatanya dilakukan pemerintah dalam bidnagbidang tertentu; Keempat, Kebijakan mungkin berbentuk positif, mungkin pula negatif. Dalam bentuknya yang positif, kebijakan negara mungkin akan mencakup beberapa bentuk tindakan pemerintah yang dimaksudkan untuk mempengaruhi masalah tertentu, sementara dalam bentuknya yang negatif, kebijakan

\footnotetext{
${ }^{4}$ Sri Hartini dan Abdul Aziz Nassihudin, Pengisian Jabatan Sekretaris Desa Di Kabupaten Banyumas (Studi Tentang Kebijakan Pengisian Jabatan Sekretaris Desa), Jurnal Dinamika Hukum, Vol 8 Nomor 1 Januari 2008, Purwokerto: $\mathrm{FH}$. Unsoed, hlm. 18

${ }^{5}$ Ibid, hlm. 19

${ }^{6}$ Ibid, hlm 19.
} 
kemungkinan meliputi keputusan-keputusan pejabat pemerintah untuk tidak melakukan tindakan apapun dalam masalah-masalah di mana campur tangan pemerintah justrus diperlukan.

Solichin Abdul Wahab mengemukakan bahwa istilah kebijakan sendiri masih terjadi silang pendapat dan merupakan ajang perdebatan para ahli. Maka untuk memahami istilah kebijakan, Solichin Abdul Wahab memberikan beberapa pedoman sebagai berikut $^{7}: 1$ ). Kebijakan harus dibedakan dari keputusan; 2). Kebijakan sebenarnya tidak serta merta dapat dibedakan dari administrasi; 3).Kebijakan mencakup perilaku dan harapanharapan; 4). Kebijakan mencakup ketiadaan tindakan ataupun adanya tindakan; 5). Kebijakan biasanya mempunyai hasil akhir yang akan dicapai; 6). Setiap kebijakan memiliki tujuan atau sasaran tertentu baik eksplisit maupun implicit; 7). Kebijakan muncul dari suatu proses yang berlangsung sepanjang waktu; 8). Kebijakan meliputi hubungan-hubungan yang bersifat antar organisasi dan yang bersifat intra organisasi; 9). Kebijakan publik meski tidak ekslusif menyangkut peran kunci lembagalembaga pemerintah; 10). Kebijakan itu dirumuskan atau didefinisikan secara subyektif.

Sementara itu Hogwood dan Lewis A. Gunn dalam Wahab mengelompokkan pengertian kebijakan dalam 10 arti, yaitu ${ }^{8}$ : a). Policy as a label for a field of activity (kebijakan sebagai sebuah label atau merk bagi suatu bidang kegiatan pemerintah); b.) Policy as an expression of general purpose desired state of affairs (kebijakan sebagai suatu pernyataan mengenai tujuan umum atau keadaan tertentu yang dikehendaki); c. Policy as spesific proposals (kebijakan sebagai suatu usulan khusus); d.) Policy as decision of government (kebijakan sebagai keputusan-keputusan pemerintah);e.) Policy as formal authorization (kebijakan sebagai bentuk otorisasi atau pengesahan formal); f.) Policy as programme (kebijakan sebagai program); g.) Policy as

\footnotetext{
7 Solichin Abdul Wahab, Pengantar Analisis Kebijakan Publik, Malang: UMM Pres, 2008, h/m 40.

${ }^{8}$ Ibid, hlm 18
}

output (kebijakan sebagai keluaran); h. Policy as outcome (kebijakan sebagai hasil akhir); i.) Policy as a theory or model (kebijakan sebagai teori atau model); j.) Policy as process (kebijakan sebagai proses).

W.I Jenkins ${ }^{9}$, yang memandang kebijakan sebagai "a set of interrelative decision..concerning the selection of goal and the means of achieving them within a specified situation". (rangkaian keputusan yang saling terkait dengan pilihan tujuan-tujuan dan caracara mencapainya dalam situasi tertentu)" J.K. Friend dan kawan-kawannya ${ }^{10}$ menyebutkan kebijakan adalah "policy is essentiallly a stance which, once articulated, contributes to the context within which a succession of future decision will be made". ( kebijakan pada hakekatnya adalah suatu bentuk penyikapan tertentu yang sekali dinyatakan, akan mempengaruhi keberhasilan keputusankeputusan yang akan dibuat).

Berdasarkan ketentuan Pasal 1 ayat 2 UU No 22 Tahun 2014 tentang Pemerintahan Daerah, adalah penyelenggaraan urusan pemerintahan oleh pemerintahan daerah dan DPRD menurut asas otonomi dan tugas pembantuan dengan prinsip otonomi yang seluasluasnya dalam sistem dan prinsip Negara Kesatuan Republik Indonesia sebagaimana dimaksud dalam Undang-Undang Dasar Negara Republik Indonesia Tahun 1945. Melihat definisi pemerintahan daerah seperti yang telah dikemukakan di atas, maka yang dimaksud pemerintahan daerah disini adalah penyelenggaraan daerah otonom oleh pemerintah daerah dan DPRD menurut asas desentralisasi dan unsur penyelenggara pemerintah daerah adalah gubernur, bupati atau walikota dan perangkat daerah. Pemerintah daerah mempunyai kewenangan yang besar untuk merencanakan, merumuskan, melaksanakan, serta mengevaluasi kebijakan dan program pembangunan yang sesuai dengan kebutuhan masyarakat setempat (Agustino, 2008: 1). Sekarang Pemerintah daerah tidak

\footnotetext{
${ }^{9}$ Ibid, hlm 40

${ }^{10}$ Ibid, hlm 41
} 
lagi sekedar sebagai pelaksana operasional kebijakan-kebijakan yang telah ditetapkan dan ditentukan oleh pusat, tetapi lebih dari itu diharapkan dapat menjadi agen penggerak pembangunan di tingkat daerah atau lokal.

Teori Kewenangan terdiri yaitu terdiri dari ${ }^{11}$ : 1). Atribusi adalah pemberian wewenang pemerintahan oleh pembuat undang-undang kepada organ pemerintah; 2). Delegasi (delegatie) adalah penyerahan wewenang dari pejabat yang lebih tinggi kepada pejabat yang lebih rendah; 3). Mandat (mandaat) adalah pelimpahan wewenang atau perintah yang diberikan oleh seorang pejabat atas nama jabatannya kepada pihak ketiga untuk melaksanakan sebagian tugas pejabat itu atas jabatan.

Berdasarkan Pasal 10 Undang-undang Nomor 23 Tahun 2014 tentang Pemerintah Daerah urusan Pemerintahan Absolut terdiri dari : a).politik luar negeri; b). pertahanan;c). keamanan;d). yustisi;e). moneter dan fiskal nasional; dan f). agama.

Berdasarkan Pasal 12 ayat 1 Undang-undang Nomor 23 Tahun 2014 tentang Pemerintah Daerah yaitu urusan pemerintahan konkuren terdiri dari urusan pemerintahan wajib dan pilihan. Urusan pemerintahan wajib terbagi lagi menjadi Urusan Pemerintahan yang berkaitan dengan Pelayanan Dasar dan Urusan Pemerintahan yang tidak berkaitan dengan Pelayanan Dasar. Urusan wajib yang berkaitan dengan pelayanan dasar adalah sebagai berikut: a).pendidikan; b).kesehatan; c).pekerjaan umum dan penataan ruang; d).perumahan rakyat dan kawasan permukiman;e).ketentraman, ketertiban umum dan perlindungan masyarakat:f).sosial.

Berdasarkan Pasal 12 ayat 2 Undang-undang Nomor 23 Tahun 2014 tentang Pemerintah Daerah Urusan wajib yang tidak terkait dengan pelayanan dasar adalah sebagai berikut :a). tenaga kerja;b). pemberdayaan perempuan dan

11 Yuslim, Gagasan Pengaturan Kewenangan Gubernur Sebagai Wakil Pemerintah Setelah Perubahan UndangUndang Dasar 1945, Jurnal Yustisia, Edisi 86 Mei - Agustus 2013, Surakarta: FH UNS, hlm. 82. perlindungan anak;c). Pangan; d).pertanahan;e). lingkungan hidup;f).administrasi kependudukan dan pencatatan sipil;g).pemberdayaan masyarakat dan desa; $h$ ).pengendalian penduduk dan keluarga berencana;i).perhubungan;j).komunikasi dan informatika;k).koperasi, usaha kecil dan menengah;l).penanaman modal;m).kepemudaan dan olah raga;n).statistik;0).persandian; p).kebudayaan;q).perpustakaan; $r$ ).kearsipan.

Berdasarkan Pasal 12 ayat 3 Undang-undang Nomor 23 Tahun 2014 tentang Pemerintah Daerah Urusan pilihan adalah sebagai berikut :

a. kelautan dan perikanan

b. pariwisata

c. pertanian

d. kehutanan

e. energi dan sumber daya mineral

$f$. perdagangan

g. perindustrian

h. transmigrasi

Berdasarkan Pasal 10 Undang-undang Nomor 23 Tahun 2014 tentang Pemerintah Daerah Pembagian urusan pemerintahan konkuren antara Pemerintah Pusat dan Daerah provinsi serta Daerah kabupaten/kota sebagaimana disebutkan diatas didasarkan pada prinsip akuntabilitas, efisiensi, dan eksternalitas, serta kepentingan strategis nasional. Berikut kriteria-kriteria urusan pemerintahan pusat, daerah provinsi dan daerah kabupaten/kota. Kriteria Urusan Pemerintahan yang menjadi kewenangan Pemerintah Pusat adalah:

a. Urusan Pemerintahan yang lokasinya lintas Daerah provinsi atau lintas negara;

b. Urusan Pemerintahan yang penggunanya lintas Daerah provinsi atau lintas negara;

c. Urusan Pemerintahan yang manfaat atau dampak negatifnya lintas Daerah provinsi atau lintas negara;

d. Urusan Pemerintahan yang penggunaan sumber dayanya lebih efisien apabila dilakukan oleh Pemerintah Pusat; dan/atau

e. Urusan Pemerintahan yang peranannya strategis bagi kepentingan nasional. 
Kriteria Urusan Pemerintahan yang menjadi kewenangan pemerintah derah provinsi adalah:

a. Urusan Pemerintahan yang lokasinya lintas Daerah kabupaten/kota;

b. Urusan Pemerintahan yang penggunanya lintas Daerah kabupaten/kota;

c. Urusan Pemerintahan yang manfaat atau dampak negatifnya lintas Daerah kabupaten/kota; dan/atau

d. Urusan Pemerintahan yang penggunaan sumber dayanya lebih efisien apabila dilakukan oleh Daerah Provinsi.

Kriteria Urusan Pemerintahan yang menjadi kewenangan Pemerintah Daerah Kabupaten/Kota adalah:

a. Urusan Pemerintahan yang lokasinya dalam Daerah kabupaten/kota;

b. Urusan Pemerintahan yang penggunanya dalam Daerah kabupaten/kota;

c. Urusan Pemerintahan yang manfaat atau dampak negatifnya hanya dalam Daerah kabupaten/kota; dan/atau

d. Urusan Pemerintahan yang penggunaan sumber dayanya lebih efisien apabila dilakukan oleh Daerah kabupaten/kota.

Melihat konteks di atas kewenangan dari pemerintah daerah sangatlah kompleks, karena mempunyai wewenang yang strategis dalam berbagai sektor. Kewenangan-kewenangan tersebut diwujudkan dalam bentuk rencana kerja pemerintah daerah dan dijabarkan dalam bentuk pendapatan, belanja dan pembiayaan daerah yang dikelola dalam sistem pengelolaan daerah yang dilakukan secara efektif, efisien, transparan, akuntabel, adil, dan taat pada peraturan perundang-undangan. Oleh karena itu perkembangan suatu daerah dipengaruhi oleh kinerja dari dari pemerintah daerah. Pemerintah daerah yang memiliki kinerja baik dan profesional akan mampu meningkatkan potensi daerah yang dikelolanya.

Konservasi Sumber Daya Air Berdasarkan Pasal 1 (satu) ayat 2 (dua) Undang-undang Nomor 32 Tahun 2009 tentang Perlindungan dan Pengelolaan Lingkungan Hidup memberikan pengertian tentang Perlindungan dan pengelolaan lingkungan hidupadalah upaya sistematis dan terpadu yangdilakukan untuk melestarikan fungsi lingkunganhidup dan mencegah terjadinya pencemaran dan/atau kerusakan lingkungan hidup yang meliputi perencanaan, pemanfaatan, pengendalian,pemeliharaan, pengawasan, dan penegakan hukum. Sedangkan pengertian Lingkungan Hidup menurut Pasal 1 ayat 1 Undang-undang Nomor 32 Tahun 2009 tentang Perlindungan dan Pengelolaan Lingkungan Hidup yaitu Lingkungan hidup adalah kesatuan ruang dengansemua benda, daya, keadaan, dan makhluk hidup,termasuk manusia dan perilakunya, yangmempengaruhi alam itu sendiri, kelangsungan perikehidupan, dan kesejahteraan manusia sertamakhluk hidup lain. Sedangkan definisi Lingkungan menurut Kamus Besar Bahasa Indonesia (KKBI) berarti, (1) daerah (kawasan dsb) yg termasuk di dalamnya; (2) bagian wilayah dl kelurahan yg merupakan lingkungan kerja pelaksanaan pemerintahan desa; (3) golongan; kalangan: ia berasal $d r ~ \sim$ bangsawan; (4) semua yg mempengaruhi pertumbuhan manusia atau hewan: kita harus mencegah pencemaran sedangkan lingkungan hidup mempunyai arti (1) kesatuan ruang dng semua benda, daya, keadaan, dan makhluk hidup, termasuk manusia dan perilakunya yg mempengaruhi perikehidupan dan kesejahteraan manusia serta makhluk hidup lainnya; (2) lingkungan di luar suatu organisme yg terdiri atas organisme hidup, spt tumbuhan, hewan, dan manusia. Pengertian lingkungan hidup adalah semua benda, daya dan kondisi yang terdapat dalam suatu tempat atau ruang tempat manusia atau makhluk hidup berada dan dapat mempengaruhi hidupnya. Istilah lingkungan hidup, dalam bahasa Inggris disebut dengan environment, dalam bahasa Belanda disebut dengan millieu atau dalam bahasa Perancis disebut dengan l'environment. Dalam kamus lingkungan hidup yang disusun Michael Allaby, lingkungan hidup itu diartikan sebagai: the physical, chemical and biotic condition surrounding and organism. S.J. MCNaughton dan Larry $L$. Wolf mengartikannya dengan semua faktor eksternal yang bersifat biologis dan fisika yang langsung mempengaruhi kehidupan, 
pertumbuhan, perkembangan dan reproduksi organisme Otto Soemarwoto, seorang ahli ilmu lingkungan (ekologi) terkemuka mendefinisikannya sebagai berikut: Lingkungan adalah jumlah semua benda dan kondisi yang ada dalam ruang yang kita tempati yang mempengaruhi kehidupan kita. Munadjat Danusaputro, ahli hukum lingkungan terkemuka dan Guru Besar Hukum Lingkungan Universitas Padjadjaran mengartikan lingkungan hidup sebagai semua benda dan kondisi, termasuk di dalamnya manusia dan tingkah perhuatannya, yang terdapat dalam ruang tempat manusia berada dan mempengaruhi hidup serta kesejahteraan manusia dan jasad hidup lainnya.

Konservasi itu sendiri merupakan berasal dari kata Conservation yang terdiri atas kata con (together) dan servare (keep/save) yang memiliki pengertian mengenai upaya memelihara apa yang kita punya (keep/save what you have), namun secara bijaksana (wise use). Menurut Kamus Besar Bahasa Indonesia (KBBI) konservasi berarti (1) pemeliharaan dan perlindungan sesuatu secara teratur untuk mencegah kerusakan dan kemusnahan dng jalan mengawetkan; pengawetan; pelestarian; (2) proses menyaput bagian dalam badan mobil, kapal, dsb untuk mencegah karat. Ide ini dikemukakan oleh Theodore Roosevelt (1902) yang merupakan orang Amerika pertama yang mengemukakan tentang konsep konservasi. Konservasi dalam pengertian sekarang, sering diterjemahkan sebagai the wise use of nature resource (pemanfaatan sumberdaya alam secara bijaksana). Konservasi juga dapat dipandang dari segi ekonomi dan ekologi dimana konservasi dari segi ekonomi berarti mencoba mengalokasikan sumberdaya alam untuk sekarang, sedangkan dari segi ekologi, konservasi merupakan alokasi sumberdaya alam untuk sekarang dan masa yang akan datang. Apabila merujuk pada pengertiannya, konservasi didefinisikan dalam beberapa batasan, sebagai berikut : 1).Konservasi menurut American Dictionary adalah menggunakan sumberdaya alam untuk memenuhi keperluan manusia dalam jumlah yang besar dalam waktu yang lama; 2).Konservasi menurut Randall adalah alokasi sumberdaya alam antar waktu (generasi) yang optimal secara sosial ; 3).Konservasi menurut IUCN adalah merupakan manajemen udara, air, tanah, mineral ke organisme hidup termasuk manusia sehingga dapat dicapai kualitas kehidupan manusia yang meningkat termasuk dalam kegiatan manajemen adalah survai, penelitian, administrasi, preservasi, pendidikan, pemanfaatan dan latihan; 4). Konservasi menurut WCS adalah manajemen penggunaan biosfer oleh manusia sehingga dapat memberikan atau memenuhi keuntungan yang besar dan dapat diperbaharui untuk generasigenerasi yang akan datang.

Menurut Anik Sarminingsih bahwa dalam pengelolaan sumberdaya air menganut tujuh azas seperti berikut ${ }^{12}$ :

1. Asas Kelestarian, mengandung pengertian bahwa pendayagunaan sumber daya air diselenggarakan dengan menjaga kelestarian fungsi sumber daya air secara berkelanjutan.

2. Asas Keseimbangan, mengandung pengertian untuk senantiasa menempatkan fungsi sosial, fungsi lingkungan hidup, dan fungsi ekonomi secara harmonis.

3. Asas Kemanfaatan Umum,mengandung pengertian bahwa pengelolaan sumber daya air dilaksanakan untuk memberikan manfaat sebesar-besarnya bagikepentingan umum secara efektif dan efisien.

4. Asas Keterpaduan dan Keserasian, mengandung pengertian bahwa pengelolaan sumber daya air dilakukansecara terpadu dalam mewujudkan keserasian untuk berbagai kepentingandengan memperhatikan sifat alami air yang dinamis.

5. Asas Keadilan, mengandung pengertianbahwa pengelolaan sumber daya air dilakukan secara merata ke seluruhlapisan masyarakat di wilayah tanah air sehingga setiap warga negara berhakmemperoleh kesempatan yang sama

\footnotetext{
12 Anik Sarminingsih, Evaluasi Kekritisan Lahan Daerah Aliran Sungai (DAS) dan Mendesaknya Langkah-Langkah Konservasi Air, Jurnal PRESIPITASI Vol. 2 No.1 September 2007, Halaman 8-14
} 
untuk berperan dan menikmati hasilnya secara nyata, dengan tetap memberikan perlindungan kepada lapisan masyarakat yang tingkat ekonominya berkekurangan.

6. Asas Kemandirian, mengandung pengertian bahwa pengelolaan sumber daya air dilakukan dengan memperhatikan kemampuan gan keunggulan. norma dan sumber daya setempat.

7. Asas Transparansi dan Akuntabilitas, mengandung pengertian bahwa pengelolaan sumber daya air dilakukan secara terbuka dan bartanggungjawab.

\section{Fungsi Hukum sebagai Rekayasa Sosial}

Kebijakan pemerintah dalam konservasi sumber daya air adalah rekayasa sosial untuk membentu masyarakat yang peduli adak lingkungan. Ini berkaitan dengan fungsi hukum, maka yang menjadi pokok kajian adalah sejauh mana hukum dapat memberikan peranan yang positif dalam masyarakat, baik dalam arti terhadap setiap individu, maupun dalam arti masyarakat secara keseluruhan hukum sebagai kaidah, atau hukum sebagai teori. Hukum dalam pengertian Pound dimaknai sebagai sarana untuk melakukan pembaruan di masyarakat. gagasan Pound ini diadopsi oleh Mochtar Kusumaatmadja yang mengemukakan satu teori yang juga berangkat dari gagasan bahwa hukum mesti difungsikan sebagai sarana rekayasa sosial, yang disebutnya teori hukum pembangunan. Penelitian ini berupaya menjabarkan teori hukum pembangunan Mochtar Kusumaatmadja dan relevansinya di masa kini. Teori hukum pembangunan pertama kali diwacanakan Mochtar Kusumaatmadja teori itu jauh-jauh hari sudah dimasukkan dalam materi hukum dalam Pelita I ${ }^{13}$ Dalam hubungan ini, banyak ahli yang telah mengemukakan pendapatnya, seperti Lawrence M. Friedman

\footnotetext{
${ }^{13}$ Atmasasmita, Romli. 2012. Teori Hukum Integratif: Rekonstruksi terhadap Teori Hukum Pembangunan dan Teori Hukum Progresif. Yogyakarta: Genta Publshing, hlm. 56.
}

yang dikutip oleh Soleman B. Taneko ${ }^{14}$ yang menyatakan bahwa fungsi hukum itu meliputi :

1. Pengawasan/Pengendalian Sosial (Social Control).

2. Penyelesaian Sengketa (Dispute Settlement).

3. Rekayasa Sosial (Social Engineering, Redistributive, atau Innovation)".

Menurut ahli tersebut di atas, pada dasarnya hukum mempunyai tiga fungsi yang harus diperankan dalam suatu masyarakat. Dalam hubungan ini, juga oleh Soerjono Soekanto mengemukakan fungsi hukum yang terdiri dari ${ }^{15}$ :

1 Untuk memberikan pedoman kepada warga masyarakat, bagaimana mereka harus bertingkah laku atau bersikap dalam menghadapi masalah-masalah dalam masyarakat yang terutama menyengkut kebutuhan-kebutuhan pokok.

2 Untuk menjaga keutuhan masyarakat yang bersangkutan.

3 Memberikan pegangan kepada masyarakat yang bersangkutan untuk mengadakan pengendalian sosial (Social Control)".

Fungsi hukum sebagai alat rekayasa sosial yang semakin penting dalam era pembangunan ditegaskan pula oleh Muchtar Kusumaatmadja seperti yang dikutip oleh Soleman B. Taneko ${ }^{16}$ mengemukakan bahwa "Di Indonesia fungsi hukum di dalam pembangunan adalah sebagai sarana pembangunan masyarakat. Hal ini didasarkan pada anggapan bahwa adanya ketertiban dalam pembangunan merupakan suatu yang dianggap penting dan sangat diperlukan. Di samping itu, hukum sebagai tata kaidah dapat berfungsi untuk menyalurkan arah-arah kegiatan warga masyarakat ke tujuan yang dikehendaki oleh perubahan tersebut.

\footnotetext{
${ }^{14}$ Taneko, Soleman B. Pokok-Pokok Studi Hukum Dalam Masyarakat, PT. Raja Grafindo Persada 1992 h/m 37

15 Soerjono Soekanto, Pokok-Pokok Sosiologi Hukum, Rajawali Pers, Alumni, Bandung, 1992, hlm16.

16 Soleman B. Taneko, Pokok-Pokok Studi Hukum dalam Masyarakat, Jakarta: PT Raja Grafindo Persada, 1993, hlm. 36
} 
Sudah tentu bahwa fungsi hukum di atas seyogianya dilakukan, di samping fungsi hukum sebagai sistem pengendalian sosial". Ini berarti bahwa disamping fungsi hukum sebagai alat pengendalian sosial, juga salah satu fungsi lainnya yang sangat penting dan bahkan justru harus dilaksanakan dalam era pembangunan, adalah fungsinya sebagai alat rekayasa sosial, sebagai alat rekayasa harus diarahkan kepada hal-hal yang positif dan bukan sebaliknya.

Berdasakan pendapat yang dikemukakan di atas mengenai fungsi hukum, maka pada dasarnya kedua pendapat tersebut adalah sama, kendatipun dalam formulasi yang berbeda. Secara kuantitatif fungsi hukum yang terdiri tiga seperti tersebut di atas, oleh Soleman B. Taneko, justru mengemukakan fungsi hukum mencakup lebih dari tiga jenis seperti ungkapannya yang menyatakan bahwa fungsi hukum yang dimaksudkan antara lain meliputi :

1 Memberikan pedoman/pengarahan pada warga masyarakat untuk berperilaku.

2 Pengawasan/Pengendalian sosial (Social Control).

3 Penyelesaian sengketa (Dispute Settlement).

4 Rekayasa sosial (Social Engineering).

Kendatipun dalam pendapat yang terakhir menyebutkan empat fungsi hukum, yaitu sebagai rekayasa sosial, pada dasarnya tercakup atau inklusif pada fungsi hukum lainnya. Dikatakan demikian, karena fungsi hukum sebagai pedoman atau pengarahan masyarakat, akan berdampak pula sebagai upaya untuk melakukan perubahan dalam masyarakat, sebagaimana makna fungsi hukum sebagai alat rekayasa sosial. Dengan demikian, kiranya dapat dimaklumi, bahwa hukum di tengah-tengah masyarakat mempunyai peranan yang sangat penting, terutama dilihat dari segi fungsi yang diembannya, dan diarahkan kepada terciptanya suatu kondisi yang sangat diperlukan oleh masyarakat dalam pergaulan hidupnya. Suatu masyarakat di manapun di dunia ini, tidak ada yang statis. Masyarakat manapun senantiasa mengalami perubahan, hanya saja ada masyarakat yang perubahannya pesat dan ada pula yang lamban. Di dalam menyesuaikan diri dengan perubahan itulah, fungsi hukum sebagai a tool of engineering, sebagai perekayasa sosial, sebagai alat untuk merubah masyarakat ke suatu tujuan yang diinginkan bersama, sangat berarti.

Hukum sangat dipengaruhi oleh ideologi, politik, ekonomi, sosial, budaya. tidak hanya sekedar kemauan pemerintah. Suatu logika yang terbuka, perkembangan kebutuhan masyarakat sangat mempengaruhi pertumbuhan hukum di dalam masyarakat. Politik sangat mempengaruhi pertumbuhan hukum di dalam masyarakat ${ }^{17}$. Hukum berasal dari pemerintah dalam hal ini menurut Bismar Nasution apa yang disebutnya dengan top down. Pemerintah disini dalam konteks badan eksekutif. jika dilihat dalam konteks pemerintah daerah, hasilnya yaitu Peratuarn Daerah, Keputusan Kepala Daerah, Keputusan Kepala Daerah Kabupaten Kota, Peraturan Desa. Hukum itu berperan untuk merubah keadaan masyarakat seperti apa yang diinginkan hukum tersebut. Hukum dapat melakukan perubahan secara paksa. Agar mencapak kondisi yang diinginkan oleh hukum ${ }^{18}$. Terkait dengan uraian tersebut diatas rencana program dan kegiatan lima tahunan yang diuraikan dalam dokumen Rencana Pembangunan Jangka Menengah Daerah (RPJMD) yang merupakan hasil kesepakatan seluruh unsur pelaku pembangunan di Kabupaten adalah sebuah dokumen yang merupakan alat (tool) bagi pemerintah daerah sebagaimana yang dimaksud dalam pandangan Roscoe Pound. Pemerintah daerah membuat Peraturan Daerah Kabupaten Kuningan Nomor 12 Tahun 2007 tentang Konservasi Sumber Daya Air untuk mengatur masyarakat ke arah seperti yang diinginkan ini mulai terbukti dengan adanya kepedualian masyarakat dalam pelestarian yaitu dengan marahnya masyarakat dengan penebangan pohon yang berada dipasar cilimus ${ }^{19}$.

\footnotetext{
${ }^{17}$ Mahmul Siregar. Modul Perkuliahan Teori Hukum : TeoriTeori Hukum Sociological Jurisprudence. Sekolah Pasca Sarjana Universitas Sumatera Utara. 2008

18 Bismar Nasution. Catatan perkuliahan politik hukum. Sekolah Pasca Sarjana Universitas Sumatera Utara. 2008 ${ }^{19} \mathrm{http}$ ///www.radarcirebon.com/warga-marah-pohon-tuaikon-cilimus-itu-ditebang.html diakses pada tanggal 25 Nopember 2016 jam 20.00 wib.
} 


\section{Sistem Hukum}

Gustav Radbruch adalah seorang filosof hukum dan seorang legal scholar dari Jerman yang terkemuka yang mengajarkan konsep tiga ide unsur dasar hukum. Ketiga konsep dasar tersebut dikemukakannya pada era Perang Dunia II. Tujuan hukum yang dikemukakannya tersebut oleh berbagai pakar diidentikkan juga sebagai tujuan hukum Adapun tiga tujuan hukum tersebut adalah kepastian, keadilan, dan kemanfaatan. Sistem hukum dalam pandangan Friedman terdiri dari tiga komponen ${ }^{20}$, yakni komponen struktur hukum (legal structure), komponen substansi hukum (legal substance) dan komponen budaya hukum (legal culture). Struktur hukum (legal structure) merupakan batang tubuh, kerangka, bentuk abadi dari suatu sistem. Substansi hukum (legal substance) aturan-aturan dan norma-norma actual yang dipergunakan oleh lembaga-lembaga, kenyataan, bentuk perilaku dari para pelaku yang diamati di dalam sistem. Adapun kultur atau budaya hukum (legal culture) merupakan gagasan-gagasan, sikap-sikap, keyakinan-keyakinan, harapanharapan dan pendapat tentang hukum. Dalam perkembangannya, Friedman menambahkan pula komponen yang keempat, yang disebutnya komponen dampak hukum (legal impact). Dengan komponen dampak hukum ini yang dimaksudkan adalah dampak dari suatu keputusan hukum yang menjadi objek kajian peneliti. Berkaitan dengan budaya hukum (legal culture) ini, menurut Roger Cotterrell, konsep budaya hukum itu menjelaskan keanekaragaman ide tentang hukum yang ada dalam berbagai masyarakat dan posisinya dalam tatanan sosial. Ide-ide ini menjelaskan tentang praktik-praktik hukum, sikap warga Negara terhadap hukum dan kemauan dan ketidakmauannya untuk mengajukan perkara, dan signifikansi hukum yang relatif, dalam menjelaskan pemikiran dan perilaku yang lebih luas di luar praktik dan

\footnotetext{
20 Suwari Akhmaddhian, Penegakan Hukum Lingkungan Dan Pengaruhnya Terhadap Pertumbuhan Ekonomi Di Indonesia (Studi Kebakaran Hutan Tahun 2015), Jurnal Unifikasi Vol.3 Nomor 1 Januari 2016, Kuningan: FH Universitas Kuningan, hlm.7.
}

bentuk diskursus khusus yang terkait dengan lembaga hukum. Dengan demikian, variasi budaya hukum mungkin mampu menjelaskan banyak tentang perbedaan-perbedaan cara di mana lembaga hukum yang nampak sama dapat berfungsi pada masyarakat yang berbeda ${ }^{21}$. Substansi hukum dalam wujudnya sebagai peraturan perundang-undangan, telah diterima sebagai instrumen resmi yang memeproleh aspirasi untuk dikembangkan, yang diorientasikan secara pragmatis untuk menghadapi masalah-masalah sosial yang kontemporer.

Hukum dengan karakter yang demikian itu lebih dikenal dengan konsep hukum law as a tool of social engineering dari Roscoe Pound, atau yang di dalam terminologi Mochtar Kusumaatmadja disebutkan sebagai hukum yang berfungsi sebagai sarana untuk membantu perubahan masyarakat. ${ }^{22}$ Karakter keberpihakan hukum yang responsif ini, sering disebutkan sebagai hukum yang emansipatif. Hukum yang emansipatif mengindikasikan sifat demokratis dan egaliter, yakni hukum yang memberikan perhatian pada upaya memberikan perlindungan hak-hak asasi manusia dan peluang yang lebih besar kepada warga masyarakat yang lemah secara sosial, ekonomi dan politis untuk dapat mengambil peran partisipatif dalam semua bidang kehidupan bermasyarakat, berbangsa dan bernegara. Dikatakan bahwa hukum yang responsif terdapat di dalam masyarakat yang menjunjung tinggi semangat demokrasi. Hukum responsif menampakkan ciri bahwa hukum ada bukan demi hukum itu sendiri, bukan demi kepentingan praktisi hukum, juga bukan untuk membuat pemerintah senang, melainkan hukum ada demi kepentingan rakyat di dalam masyarakat. ${ }^{23}$ Kebijakan pemerintah daerah dalam konservasi sumber daya air memerlukan dukungan dari aparat pemerintah

\footnotetext{
${ }^{21}$ Mochtar Kusumaatmadja, 1986, Fungsi dan Perkembangan Hukum dalam Pembangunan Nasional, Bandung: Binacipta, hal. 11.

22 Ibid, hal. 18.

23 Max Weber dalam A.A.G. Peters dan Koesriani Siswosoebroto, 1988, Hukum dan Perkembangan Sosial (Buku I), Jakarta: Sinar Harapan, hal. 483
} 
dan partisipasi masyarakat dalam rangka pelestarian lingkungan hidup.

\section{KESIMPULAN}

Fungsi hukum sebagai alat rekayasa sosial yang semakin penting dalam era pembangunan ditegaskan pula oleh Muchtar Kusumaatmadja bahwa hukum sebagai sarana pembaharuan masyarakat sesuai dengan konsep hukum law as a tool of social engineering dari Roscoe Pound. Kebijakan pemerintah daerah dalam konservasi sumber daya air tertuang dalam Peraturan Daerah Kabupaten Kuningan Nomor 12 Tahun 2007 tentang Konservasi Sumber Daya Air untuk mengatur masyarakat ke arah seperti yang diinginkan oleh pemerintah darah ini mulai terbukti dengan adanya kepedulian masyarakat dalam pelestarian lingkungan hidup yaitu dengan marahnya masyarakat kabupaten kuningan dengan penebangan pohon yang berada di pasar cilimus, hal ini membuktikan bahwa hukum dapat mempengaruhi perilaku masyarakat sesuai dengan subtansi hukum dan tujuan hukum itu sendiri.

\section{REKOMENDASI}

Kebijakan kosnervasi sumber daya air di kabupaten kuningan Peraturan Daerah Kabupaten Kuningan Nomor 12 Tahun 2007 tentang Konservasi Sumber Daya Air sudah cukup efektif, untuk meningkatkan kesadaram masyarakat maka diperlukan inovasi-inovasi untuk peningkatan kesadaran masyarakat tersebut melalui lomba-lomba kebersihan baik di tingkat kecamatan ataupun desa dan menggali nilai-nilai kearifan lokal.

\section{DAFTAR PUSTAKA}

Amiluhur Soeroso, 2007, Konservasi Lingkungan Kawasan Berbasis Manajemen Pembangunan Masyarakat, Jurnal Ekonomi Pembangunan Vol. 12 Nomor 1 April 2007.

Anik Sarminingsih, Evaluasi Kekritisan Lahan Daerah Aliran Sungai (DAS) dan Mendesaknya Langkah-Langkah
Konservasi Air, Jurnal PRESIPITASI Vol. 2 No.1 Septemberr 2007.

Ach. Wazir Ws., et al., ed. Panduan Penguatan Menejemen Lembaga Swadaya Masyarakat. Jakarta: Sekretariat Bina Desa dengan dukungan AusAID melalui Indonesia HIV/AIDS and STD Prevention and Care Project, 1999.

Holil Soelaiman. Partisipasi Sosial dalam Usaha Kesejahteraan Sosial. Bandung : STKS,1980

Isbandi Rukminto Adi. Perencanaan Partisipatoris Berbasis Aset Komunitas: dari Pemikiran Menuju Penerapan. Depok: FISIP UI Press., 2007.

Max Weber dalam A.A.G. Peters dan Koesriani Siswosoebroto, 1988, Hukum dan Perkembangan Sosial (Buku I), Jakarta: Sinar Harapan.

Mochtar Kusumaatmadja, 1986, Fungsi dan Perkem-bangan Hukum dalam Pembangunan Nasional, Bandung: Binacipta.

Lawrence M. Friedman, 1984, American Law: An invalueable guide to the many faces of the law, and how it affects our daily lives, New York: W.W. Norton \& Company.

Linda Donarika Marbun, Partisipasi Masyarakat dalam Pemeliharaan prasarana pasca program NUSSP di Kelurahan Sumur Pacing dan Manis Jaya Kota Tanggerang, Semarang: Tesis Undip, 2010.

Nana Sudiana dan Hasmana Soewandita, Pola Konservasi Sumber Daya Air di Daerah Aliran Sungai Siak, Jurnal Alami Vol. 12 Nomor 1 Tahun 2007.

Romli Atmasasmita. 2012. Teori Hukum Integratif: Rekonstruksi terhadap Teori Hukum Pembangunan dan Teori Hukum Progresif. Yogyakarta: Genta Publshing

Siti Kotijah, Implementasi Prinsip-prinsip Kehutanan dalam Rangka Konservasi Kehutanan: studi kasus di Jawa Timur, Jurnal Magister Hukum, Vol. 1 Nomor 2, Surabaya : Program Studi Magister Ilmu Hukum, Universitas Wisnuwardhana, 2010. 
Soerjono Soekanto, Ringkasan metode Penelitian Hukum Empiris, Jakarta:IndHill, 1990.

\begin{tabular}{l} 
Hukum.cet.2007, $\begin{array}{c}\text { Pengantar Pakarta : UI Press, } \\
\text { 1984. }\end{array}$ \\
\\
\hline
\end{tabular}
Sosiologi Hukum, Rajawali Pers, Alumni, Bandung.

Soleman B. Taneko, 1993, Pokok-Pokok Studi Hukum dalam Masyarakat, Jakarta: PT RajaGrafindo Persada.

Suwari Akhmaddhian, 2013, "Peran Pemerintah Daerah dalam Mewujudkan Hutan Konservasi Berdasarkan UndangUndang Nomor 41 Tahun 1999 Tentang Kehutanan (Studi di Kabupaten Kuningan)", Jurnal Dinamika Hukum . Vol. 13 No.3 September 2013, FH Unsoed, Purwokerto.

2016, Penegakan Hukum Lingkungan Dan Pengaruhnya Terhadap Pertumbuhan Ekonomi Di Indonesia (Studi Kebakaran Hutan Tahun 2015), Jurnal Unifikasi Vol.3 Nomor 1 Januari 2016, Kuningan: FH Universitas Kuningan.

http://www.radarcirebon.com/warga-marahpohon-tua-ikon-cilimus-ituditebang.html diakses pada tanggal 25 Nopember 2016 jam 20.00 wib. 